\title{
Adsorption of acid yellow dye 17 on activated carbon prepared from Euterpe oleracea: kinetic and thermodynamic studies
}

\author{
Adsorção do corante amarelo ácido 17 em carvão ativado preparado do cacho do açaí Euterpe \\ oleracea: estudos cinéticos e termodinâmico \\ Adsorción de colorante amarillo ácido 17 sobre carbón activado preparado a partir de Euterpe
}

oleracea: estudios cinéticos y termodinámicos

Received: 01/10/2022 | Reviewed: 01/13/2022 | Accept: 01/20/2022 | Published: 01/22/2022

\author{
Deusimar de Oliveira Lopes \\ ORCID: https://orcid.org/0000-0003-2001-6301 \\ Universidade Federal do Sul e Sudeste do Pará, Brazil \\ E-mail: deusimarc6h12o6@gmail.com \\ Lucas Oliveira Santos \\ ORCID: https://orcid.org/0000-0002-8525-520X \\ Universidade Federal do Sul e Sudeste do Pará, Brazil \\ E-mail: lucasuepa2016@outlook.com \\ Evair Dias Nascimento \\ ORCID: https://orcid.org/0000-0002-2821-2094 \\ Universidade Federal de São Carlos, Brazil \\ E-mail: evair190@gmail.com \\ Adriane Damasceno Vieira de Souza \\ ORCID: https://orcid.org/0000-0003-1356-9573 \\ Universidade Federal do Sul e Sudeste do Pará, Brazil \\ E-mail: adrianedamasceno@unifesspa.edu.br \\ Francisco Adriano de Oliveira Carvalho \\ ORCID: https://orcid.org/0000-0002-6025-4120 \\ Universidade Federal do Sul e Sudeste do Pará, Brazil \\ E-mail: adriano.carvalho@unifesspa.edu.br
}

\begin{abstract}
Environmental pollution has been a point of discussion in the international community and an object of investigation by research groups, which focus on the development of remediation methods. In the current study, the bunch of açaí (Euterpe oleracea) was used as a precursor for the preparation of low-cost activated carbon in order to remove the dye 17 AY 17 from the aqueous solution. The synthesis was carried out at temperatures of 500,600 and $700{ }^{\circ} \mathrm{C}$, for $2.0 \mathrm{~h}$ in a muffle furnace. The kinetic and thermodynamic mechanism of the adsorption process of the acid yellow dye 17 , and the effects of $\mathrm{pH}$, contact time and initial concentration were investigated. Activated carbon carbonized at $700{ }^{\circ} \mathrm{C}$ had the highest adsorption capacity, about of $99.9 \%$ of removal of the AY. The adsorption capacity of AY 17 was slightly $\mathrm{pH}$ dependent with a maximum value at $\mathrm{pH} 2.0$. The kinetic data show that the equilibrium time was $200 \mathrm{~min}$, and the adsorption capacity of activated carbon was $99.9 \%$ at $50 \mathrm{mg} \mathrm{L}^{-1}$ and $67.0 \%$ at $150 \mathrm{mg} \mathrm{L}^{-1}$ of adsorbate, suggesting high adsorption capacity of the material, even in the presence of high dye concentration. The adsorption process of AY 17 is described by the pseudo-second order kinetic model, and the experimental adsorption isotherms are adjusted to the Freundlich model, indicating that the adsorption of AY 17 on activated carbon occurs with the formation of multilayers. The present study shows that this low-cost material has great potential for remediation of textile effluents.
\end{abstract}

Keywords: Adsorption; Activated carbon; Acid yellow 17.

\section{Resumo}

A poluição do meio ambiente tem sido ponto de discussão na comunidade internacional e objeto de investigação por grupos de pesquisa, que têm buscado o desenvolvimento de métodos de remediação. No presente estudo, o cacho de açaí (Euterpe oleracea) foi utilizado como precursor de carvão ativado de baixo custo para a remoção do corante amarelo ácido 17 (AY 17) em solução aquosa. A síntese foi realizada nas temperaturas de 500, 600 e $700^{\circ} \mathrm{C}$, por 2,0 h em forno mufla. O mecanismo cinético e termodinâmico do processo de adsorção do corante AY 17, e os efeitos do $\mathrm{pH}$, tempo de contato e concentração inicial foram investigados para o carvão ativado com maior capacidade adsortiva. O carvão ativado carbonizado a $700{ }^{\circ} \mathrm{C}$ teve a maior capacidade adsortiva, cerca de $99,9 \%$ de remoção do AY. A capacidade de adsorção de AY 17 é ligeiramente dependente do pH, com um valor máximo em $\mathrm{pH} 2,0$. Os dados cinéticos mostram que o tempo de equilíbrio é de $200 \mathrm{~min}$, e a capacidade de adsorção do carvão ativado foi de $99,9 \%$ 
a $50 \mathrm{mg} \mathrm{L}^{-1}$ e $67,0 \%$ a $150 \mathrm{mg} \mathrm{L}^{-1}$ de adsorbato, sugerindo alta capacidade de adsorção do material, mesmo na presença de alta concentração de corante. O processo de adsorção de AY 17 é descrito pelo modelo cinético de pseudo-segunda ordem, e as isotermas experimentais de adsorção são ajustadas ao modelo de Freundlich, indicando que a adsorção de AY 17 no carvão ativado ocorre com a formação de multicamadas. O presente estudo mostra que esse material de baixo custo possui grande potencial para remediação de efluentes têxteis.

Palavras-chave: Adsorção; Carvão ativado; Amarelo ácido 17.

\section{Resumen}

La contaminación ambiental ha sido un punto de discusión en la comunidad internacional y objeto de estudio de diversos grupos de investigación, que se enfocan en el desarrollo de métodos de remediación. En el presente estudio, se utilizó el racimo de açaí (Euterpe oleracea) como precursor para la preparación de carbón activado de bajo costo, con el fin de eliminar el tinte amarillo ácido 17 (AY 17) en solución acuosa. La síntesis se llevó a cabo a temperaturas de 500, 600 y $700^{\circ} \mathrm{C}$, durante $2,0 \mathrm{~h}$ en una mufla. El mecanismo cinético y termodinámico del proceso de adsorción del tinte AY 17, y los efectos del pH, el tiempo de contacto y la concentración inicial se investigaron utilizando el tipo de carbón activado con la mayor capacidad de remoción. El carbón activado a $700{ }^{\circ} \mathrm{C}$ tuvo la mayor capacidad de adsorción, con un $99,9 \%$ de remoción AY 17. La capacidad de adsorción del AY 17 fue ligeramente dependiente del pH, alcanzando un valor máximo a pH 2,0. Los datos cinéticos muestran que el tiempo de equilibrio fue de 200 min, y la capacidad de adsorción del carbón activado fue del 99,9\% a $50 \mathrm{mg} \mathrm{L}^{-1}$ y del 67,0 \% a $150 \mathrm{mg} \mathrm{L}^{-1}$ de adsorbato, sugiriendo una alta capacidad de adsorción del material, incluso en la presencia de una alta concentración de tinte. El proceso de adsorción de AY 17 se describe mediante el modelo cinético de pseudo-segundo orden, y las isotermas de adsorción experimentales se ajustan al modelo de Freundlich, lo que indica que la adsorción de AY 17 en carbón activado ocurre con la formación de multicapas. El presente estudio muestra que este material de bajo costo posee gran potencial para la remediación de efluentes textiles.

Palabras clave: Adsorción; Carbón activado; Amarillo ácido 17.

\section{Introduction}

The contamination and degradation of the environment by polluting gases, residues from agricultural activities, organic waste, toxic chemical products and other polluting sources has been the subject of debate in today's society (Chen et al., 2020; Khattab et al., 2020; Kishor et al., 2021; Nambela et al., 2020; Sarkar et al., 2017; Ignachewski et al., 2010). These pollutants promote an imbalance in the environment, and have reduced drastically the quality of available drinking water (Kishor et al., 2021; Munagapati et al., 2021; Hynes et al., 2020; Berradi et al., 2019; Sarkar et al., 2017; Ignachewski et al., 2010). Within the industrial sector, textiles are responsible for a large part of the economy of developed and some emerging countries (Haseeb et al., 2020). However, it is estimated that for the processing of about 12-20 tons of raw material are discarded daily between 1000 and $3000 \mathrm{~m}^{3}$ of wastewater, thus promoting significant impacts on the environment (Ghaly, 2014). In addition, wastewater from activities in this sector has around 20\% of dyes (Hynes et al., 2020; Khattab et al., 2020; Berradi et al., 2019), which are potentially toxic (Hynes et al., 2020; Benkhaya et al., 2020; Berradi et al., 2019; Verma et al., 2019; Obaid et al., 2016) generating negative impacts on the environment in terms of salinity, biological oxygen demand (BOD), chemical oxygen demand (COD), pH, temperature and others (Hynes et al., 2020; Berradi et al., 2019; Parveen \& Rafique, 2018; Roy et al., 2018; Sarkar et al., 2017).

Several studies have shown that the treatment of these residues in effluents represents one of the great challenges of the textile sector, since these chemical substances have high chemical and biological stability, making their degradation difficult (Hynes et al., 2020; Khattab et al., 2020; Berradi et al., 2019; Obaid et al., 2016). In addition, the presence of color significantly contributes to the pollution of water resources by drastically reducing the penetration of sunlight, and consequently the photosynthesis capacity of aquatic plants and algae (Hynes et al., 2020; Benkhaya et al., 2020). On the other hand, the chemical activity of these substances in the human body can cause breathing difficulties, eye irritation, impairment of the cardiovascular system, mutations, tumors and affect the nervous system ( Shindhal et al., 2021; Yusop et al., 2021; Bulca et al., 2021; Achour et al., 2021; Khatri et al., 2018; Hassaan et al., 2016; Vacchi et al., 2013). Therefore, many research groups have focused on the 
development of efficient and low-cost methods that enable the removal and remediation of these pollutants, in order to alleviate possible environmental impacts and maintain the integrity of human health.

On the other hand, dyes are chemical substances that play an essential role in various industry sectors, such as textiles, printing, food, plastics, cosmetics and pharmaceutical industries, whose main objective is to add color to various products (Benkhaya et al., 2020; Berradi et al., 2019; Verma et al., 2019; Castro et al., 2018). These compounds are classified according to several criteria, including the chemical structure, which is made up of chromophore and auxochrome groups (Benkhaya et al., 2020; Berradi et al., 2019; Verma et al., 2019; Castro et al., 2018; Raman \& Kanmani, 2016). Azo dyes, for example, which have the azo chromophore group (-N=N-) is the predominant class in the textile industry, representing $70 \%$ of the dyes used in this sector (Benkhaya et al., 2020; Berradi et al., 2019; Castro et al., 2018; Sarkar et al., 2017; Lang et al., 2013). This class of textile dye is highly water soluble and easily reacts with cellulosic, protein, polyester, acrylic and polyamide fibers (Castro $e t$ al., 2018; Guaratini \& Zanoni, 2000).

Currently, several techniques are used in order to treat wastewater contaminated by dyes, including adsorption, coagulation, electrochemical treatment, photocatalytic degradation, ozone treatment and biological treatment (Achour et al., 2021; Shindhal et al., 2021; Yusop et al., 2021; Paredes-Quevedo et al., 2021; Verma et al., 2019; Khatri et al., 2018; Obaid et al., 2016;). However, a large portion are ineffective, as these substances have a very stable chemical structure and low biodegradation rate (Shindhal et al., 2021; Paredes-Quevedo et al., 2021; Benkhaya et al., 2020; Verma et al., 2019; Castro et al., 2018;). Among the most efficient techniques, adsorption stands out due to its ease of operation, simplicity of the project and, above all, to be economically viable (Achour et al., 2021; Bulca et al., 2021; Yusop et al., 2021; Paredes-Quevedo et al., 2021; Verma et al., 2019; Machrouhi et al., 2018), being, therefore, widely used to remove certain classes of contaminants from industrial effluents (Achour et al., 2021; Bulca et al., 2021; Yusop et al., 2021; Heidarinejad et al., 2020; Ugwu \& Agunwamba, 2020; Alam et al., 2020; Machrouhi et al., 2018). Studies in the literature have reported several efficient materials in the removal of aqueous contaminants such as activated carbon, zeolites, clays, biomass, fungi and bacteria (Achour et al., 2021; Heidarinejad et al., 2020; Ani et al., 2020; Alkathiri et al., 2020; Machrouhi et al., 2018).

However, due to the high costs of commercial activated carbon, alternative adsorbents that guarantee the same adsorption efficiency have been studied, with emphasis on those produced from residues from agricultural and extractive activities (Achour et al., 2021; Alam et al., 2020; Alkathiri et al., 2020; Panwar and Pawar, 2020; Kannaujiya et al., 2021; Zoroufchi Benis et al., 2020; Reza et al., 2020). Several studies report the use of these materials in the synthesis of activated carbon for remediation of effluents, such as the study by Njoku et al. (2014) who studied the efficiency of activated carbon obtained from rambutan husk (Nephelium lappaceum) in the adsorption of acid yellow dye 17 (Reza et al., 2020). Other works address the removal of acid yellow dye 17 using activated carbon obtained from eggplant residues, achieving maximum removal of $99.58 \%$ (Kannaujiya et al., 2021), and the removal of anionic acid yellow dye 17 using avocado seed powder, showing excellent removal over a wide $\mathrm{pH}$ (Munagapati et al., 2021), range and adsorption study of acid yellow dye 17 using activated carbon obtained from the rice husks, providing a maximum removal of $99.98 \%$ (Patil et al., 2015). However, most of these works use synthesis routes with inert gases, such as nitrogen and argon, which increase the cost of the process (Reza et al., 2020;.Patil et al., 2015).

In view of the aforementioned, this study focuses on synthesizing activated carbon in an open atmosphere, with high adsorption capacity, from açaí bunch (Euterpe oleracea), to remove the disodium dye 2.5-dichloro-4-[3-methyl -5-oxo-4-(4sulfonatophenyl) diazenyl-diazyl-pyrazol-1-yl] benzenesulfonate in aqueous solution, commercially known as acid yellow 17, as well as characterize the kinetic and thermodynamic mechanism of adsorption. 


\section{Experimental Part}

\subsection{Preparation of dye stock solution Acid yellow 17}

The acid yellow dye 17, namely (AY17) $\left(\mathrm{C}_{16} \mathrm{H}_{10} \mathrm{Cl}_{2} \mathrm{~N}_{4} \mathrm{Na}_{2} \mathrm{O}_{7} \mathrm{~S}_{2}\right)$, CAS number: 6359-98-4, ID 329751987, was purchased from Sigma-Aldrich company, Saint Louis, USA, at $60 \%$ content. This dye has an intense yellow color, being characterized by an absorption maximum around $402 \mathrm{~nm}$, molar absorption coefficient 14,000.00 mol ${ }^{-1} \mathrm{~L} \mathrm{~cm}^{-1}$ and molecular weight equal to $551.29 \mathrm{~g} \mathrm{~mol}^{-1}$. Ultra-pure water with a resistivity of $18 \mathrm{M} \Omega \mathrm{cm}$, purified in a purifier (Milli-Q®, Merck Millipore), was used to prepare the solutions. The $1000 \mathrm{mg} \mathrm{L}^{-1}$ standard stock solution was prepared by dissolving $1.6 \mathrm{~g}$ of the dye in $1000 \mathrm{~mL}$ of ultrapure water. Then, the solution was properly stored for the studies.

\subsection{Synthesis of adsorbents prepared from açaí bunch}

The raw material (açaí bunches) collected in the municipality of Marabá-PA, was initially washed in running water to remove unwanted solid residues and subjected to a drying process at a temperature of $80{ }^{\circ} \mathrm{C}$ in an (SSD-11L, Solidsteel) oven for $48 \mathrm{~h}$. Then, the material was crushed in a knife mill model NL-226/02 (NewLab, Brazil) and classified in a Tyler-type sieve (Bertel, Brazil) coupled to a stirrer in the pass-through mesh range above $28(0.25 \mathrm{~mm})$. After classification, $50 \mathrm{~g}$ samples of biomass were carbonized in a Magnus brand muffle oven at temperatures of $500,600,700{ }^{\circ} \mathrm{C}$ for $2.0 \mathrm{~h}$ and heating rate of $10{ }^{\circ} \mathrm{C}$ $\mathrm{min}^{-1}$. After the carbonization process, all samples were again classified in 325 mesh (0.044 mm) opening sieves and reserved for adsorption tests. The carbonized adsorbents at temperatures of 500, 600 and $700{ }^{\circ} \mathrm{C}$ were named CA-CA500, CA-CA600 and CA-CA700 respectively.

\subsection{Characterization of adsorbents by BE and BJH and IR}

The textural properties of activated carbon were determined by adsorption-desorption of $\mathrm{N}_{2}$ at $77.35 \mathrm{~K}$ using a surface analyzer (QUANTACHROME model NOVA 2200e) with liquid nitrogen of density $0.808 \mathrm{~g} \mathrm{~cm}^{-3}$. Before taking the measurements, the sample was subjected to a thermal pre-treatment at $423 \mathrm{~K}$ for $2.0 \mathrm{~h}$. The adsorption of $\mathrm{N}_{2}$ in the sample was used to calculate the specific surface area $\left(S_{\mathrm{BET}}\right)$ by the BET method (Brunauer - Emmett - Teller), while the diameter $\left(\mathrm{D}_{\mathrm{p}}\right)$ and pore volume $\left(\mathrm{V}_{\mathrm{p}}\right)$ were determined by the BJH method (Barrett - Joyner - Halenda).

The infrared spectra of the in natura and carbonized samples and CA-CA700, both in a particle size of 325 meshes, were obtained by attenuated total reflectance (ATR), using a Thermo brand spectrometer, model Nicolet iS50 FT-IR, in the spectral region $4000-400 \mathrm{~cm}^{-1}$, at $100 \mathrm{scans}$ and $4 \mathrm{~cm}^{-1}$ resolution. Data acquisition was performed using the OMNIC program, and the treatment using the origin program, version 8.0. As a pre-treatment, the samples were dried at $105{ }^{\circ} \mathrm{C}$ for 24 hours.

\subsection{Analytical curve}

From the $1000 \mathrm{mg} \mathrm{L}^{-1}$ stock solution, solutions were prepared with a volume of $2.0 \mathrm{~mL}$ of the dye in the concentration range of 0 to $22 \mathrm{mg} \mathrm{L}^{-1}$ for the construction of the analytical curve. The UV-Vis experiments were carried out in a Bel Spectro S05 spectrophotometer, at the maximum absorption wavelength $\left(\lambda_{\max }\right) 400 \mathrm{~nm}$. Sample absorbances were measured in a $1.0 \mathrm{~mL}$ quartz cuvette and $1.0 \mathrm{~cm}$ optical path.

\subsection{Adsorption experiments}

The adsorption measures were carried out in a $250 \mathrm{~mL}$ erlenmeyer flask, varying the mass of the adsorbents in the range of 0.1 to $1.0 \mathrm{~g}$, in $100 \mathrm{~mL}$ of dye solution AY 17 in the concentration range of 25 to $300 \mathrm{mg} \mathrm{L}^{-1}$, under stirring at $200 \mathrm{rpm}$ at $20{ }^{\circ} \mathrm{C}$. 
Initially, measurements were taken to evaluate the most efficient adsorbent, in which $0.20 \mathrm{~g}$ of each synthesized material was exposed to $100 \mathrm{~mL}$ of the dye at $25 \mathrm{mg} \mathrm{L}^{-1}$, under agitation in an orbital shaking incubator (SL-223) for $200 \mathrm{~min}$, at pH 7.0. Adsorbent removal capacity (\%) was measured using Equation 1:

$$
\operatorname{Remoção}(\%)=\frac{c_{0}-C_{e}}{C_{0}} \times 100
$$

Where $\mathrm{C}_{0}\left(\mathrm{mg} \mathrm{L}^{-1}\right)$ and $\mathrm{C}_{\mathrm{e}}\left(\mathrm{mg} \mathrm{L}^{-1}\right)$ are the dye concentrations initially and at equilibrium, respectively (Munagapati et al., 2021).

In a second step, measurements were carried out to evaluate the effect of the adsorbent mass in the range $(0.1$ to $1.0 \mathrm{~g})$, pH (2.0 to 9.0) and initial concentration of adsorbate ( 25 to $150 \mathrm{mg} \mathrm{L}^{-1}$ ), under the same conditions as in step 1 , at $20{ }^{\circ} \mathrm{C}$ and $200 \mathrm{rpm}$. The $\mathrm{pH}$ of the solutions was adjusted according to the studies by Salleh et al., 2011, Reza et al., 2020 and Salleh et al., 2011 in which small volumes of $0.1 \mathrm{~mol} \mathrm{~L}^{-1} \mathrm{HCl}$ or $0.1 \mathrm{~mol} \mathrm{~L}^{-1} \mathrm{NaOH}$ solutions were added until reaching the investigated $\mathrm{pH}$ value.

Therefore, the adsorption kinetics experiments of AY17 were carried out at concentrations of 50, 75, 100 and $150 \mathrm{mg} \mathrm{L}^{-}$ ${ }^{1}$ and volume of $100 \mathrm{~mL}$, in time intervals from 0 to $300 \mathrm{~min}$, in the presence of $0.5 \mathrm{~g}$ of CA-CA700, at $20{ }^{\circ} \mathrm{C}$, pH 6.0 and 200 rpm, while the equilibrium measurements were made with an interaction time of 200 min, in a wider concentration range, from 25 to $300 \mathrm{mg} \mathrm{L}^{-1}$, to improve the acquisition of equilibrium isotherms. The ability to remove $\mathrm{AY} 17$ at equilibrium $\mathrm{q}_{\mathrm{e}}\left(\mathrm{mg}^{-1}\right.$ ) was calculated from Equation 2:

$$
q_{e}\left(m g g^{-1}\right)=\frac{\left[C_{0}\left(m g L^{-1}\right)-C_{e}\left(m g L^{-1}\right)\right] V(L)}{m(g)}
$$

where $\mathrm{C}_{0}\left(\mathrm{mg} \mathrm{L}^{-1}\right)$ and $\mathrm{C}_{\mathrm{e}}\left(\mathrm{mg} \mathrm{L}^{-1}\right)$ are the concentrations of the initial and equilibrium AY17 respectively, V (L) is the volume of solution and $m(\mathrm{~g})$ is the mass of adsorbent (Munagapati et al., 2021).

\section{Results and Discussion}

\subsection{Adsorption efficiency of materials}

Table 1 shows the adsorption capacity of the three adsorbents synthesized from the açaí bunch as a function of carbonization temperature.

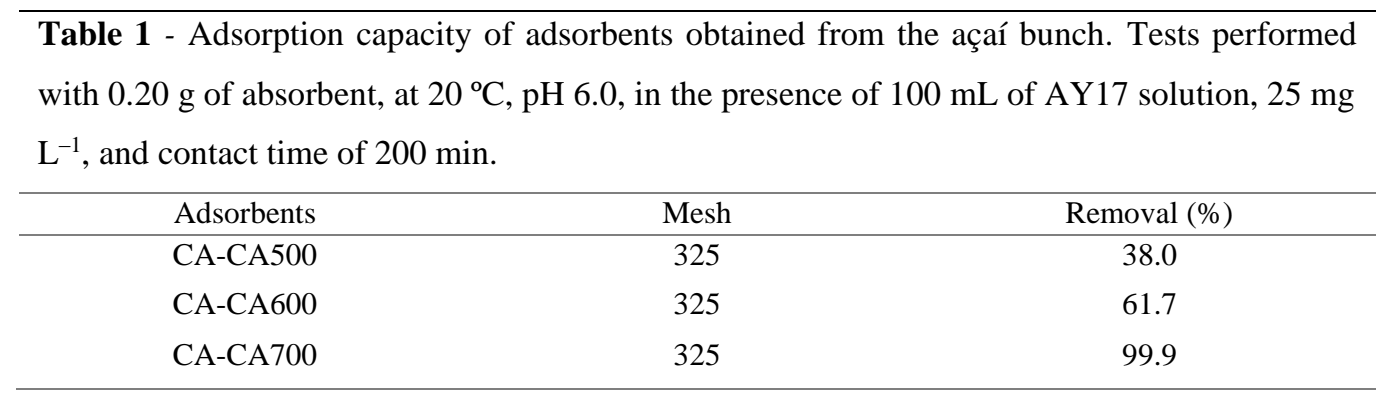

Source: Authors (2021).

Under these conditions, the data show that the increase in temperature significantly contributes to the adsorption efficiency, with removal rates of 38.0, 61.7 and 99.9\% being observed for CA-CA500, CA-CA600 and CA-CA700, respectively (Table 1). The increase of $200{ }^{\circ} \mathrm{C}$ granted an increase of $61.9 \%$ in the AY17 removal (Table 1). This removal index obtained for the CA-CA700 is very similar to other studies such as Kannaujiya et al., 2021 and Patil et al., 2015. Studies in the literature 
show that the increase in carbonization temperature produces two main effects, the first is the significant increase in the surface area of the carbonized material, and consequently a greater adsorption efficiency, and second, a significant loss of synthesis yield (Ani et al., 2020; Machrouhi et al., 2018), corroborating the data reported in the present study.

Thus, the following experiments were carried out only with the adsorbent with the highest adsorption capacity, CACA700.

\subsection{CA-CA700 characterization}

Figure 1 shows the adsorption-desorption isotherm of $\mathrm{N}_{2}$ at $77 \mathrm{~K}$ for activated carbon from the açaí bunch (CA-CA700). A The isotherm obtained presents a characteristic profile of the type IV isotherm, according to the classification of the International Union of Pure and Applied Chemistry (IUPAC), (Foo and Hameed, 2012; Sing, 1982) with an $\mathrm{H}_{4}$-type hysteresis cycle in the P/P $\mathrm{P}_{0}$ range from 0.4 to 0.99 , suggesting that the surface of CA-CA700 is predominantly constituted by mesopores (Munagapati et al., 2021; Sing, 1982; Shoaib et al., 2020; Hamza et al., 2018). The textural properties obtained by the BET and BJH methods, indicate that the material has a surface area of $353 \mathrm{~m}^{2} \mathrm{~g}^{-1}$, average pore diameter of $3.628 \mathrm{~nm}$ and pore volume of $0.046 \mathrm{~cm}^{3} \mathrm{~g}^{-1}$ corroborating the presence of mesopores in the structure, since for this type of isotherm the diameter range for mesoporous material is between 2.0 and 50 nm. (Munagapati et al., 2021; Shoaib et al., 2020; Mahmoud et al., 2020; Berradi et al., 2019; Jedynak et al., 2019; Hamza et al., 2018).

Figure 1 - $\mathrm{N}_{2}$ adsorption-desorption isotherm for CA-CA700.

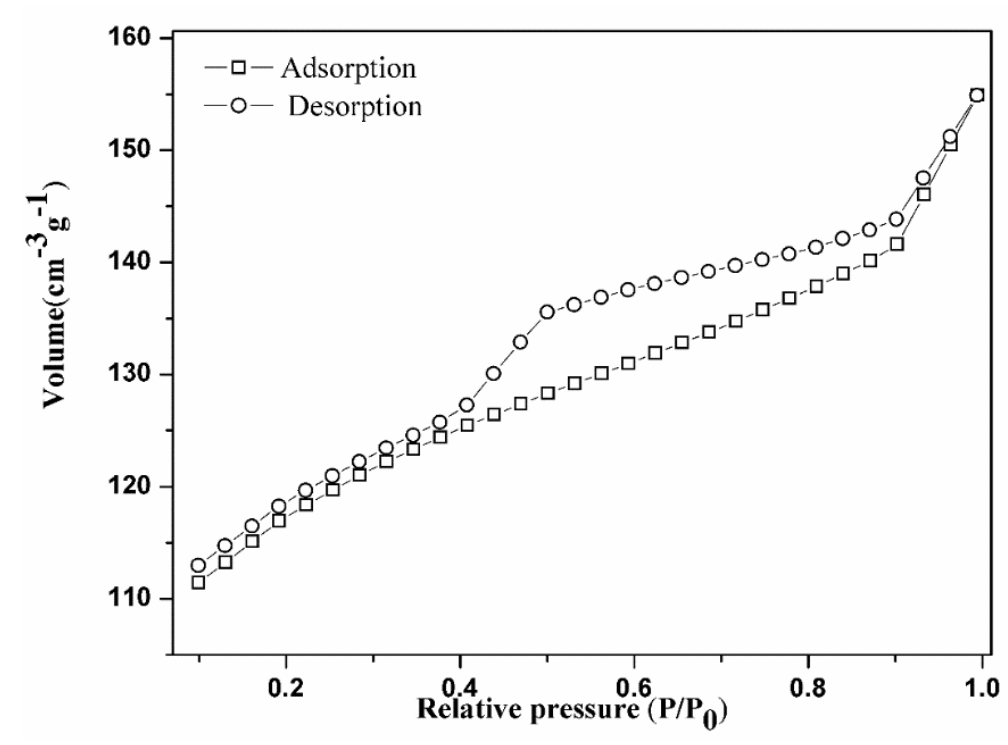

Source: Authors (2021).

The infrared spectra in the range from 4000 to $450 \mathrm{~cm}^{-1}$ for in natura sample of the açaí bunch and for the CA-CA700 adsorbent are shown in Figure 2. The FTIR spectrum of the açaí bunch biomass is characterized by the presence of a band of greater intensity at $3,385 \mathrm{~cm}^{-1}$ associated with the stretching of the hydroxyl group with hydrogen bonds in the cellulose (-OH). Other less intense bands centered at $2920 \mathrm{~cm}^{-1}$, due to axial $\mathrm{CH}_{2}$ deformation characteristic of the methyl group, $1740 \mathrm{~cm}^{-1}$ associated with the presence of the natural carbonyl group $(\mathrm{C}=\mathrm{O})$ of hemicellulose, $1610 \mathrm{~cm}^{-1}$ attributed to the stretching of the $\mathrm{C}$ bond $=\mathrm{C}$ of aromatic compounds, $1518 \mathrm{~cm}^{-1}$ contribution of primary and secondary amines, 1,160 and $1,056 \mathrm{~cm}^{-1}$ contribution of COC binding in hexoses, are observed. Carbonization promotes drastic changes in the functional groups of the biomass, characterized by an intense reduction in the contributions of oxygenated groups, which suggest the dehydration of the material. 
The CA-CA700 spectrum presents bands at 1420, 1040 and $870 \mathrm{~cm}^{-1}$ that are associated with the cellulose structure and indicate the partial degradation of the material in pyrolysis.

Figure 2 - Infrared spectra for samples of açaí biomass (Euterpe oleracea) in natura and carbonized at $700{ }^{\circ} \mathrm{C}(\mathrm{CA}-\mathrm{CA} 700)$.

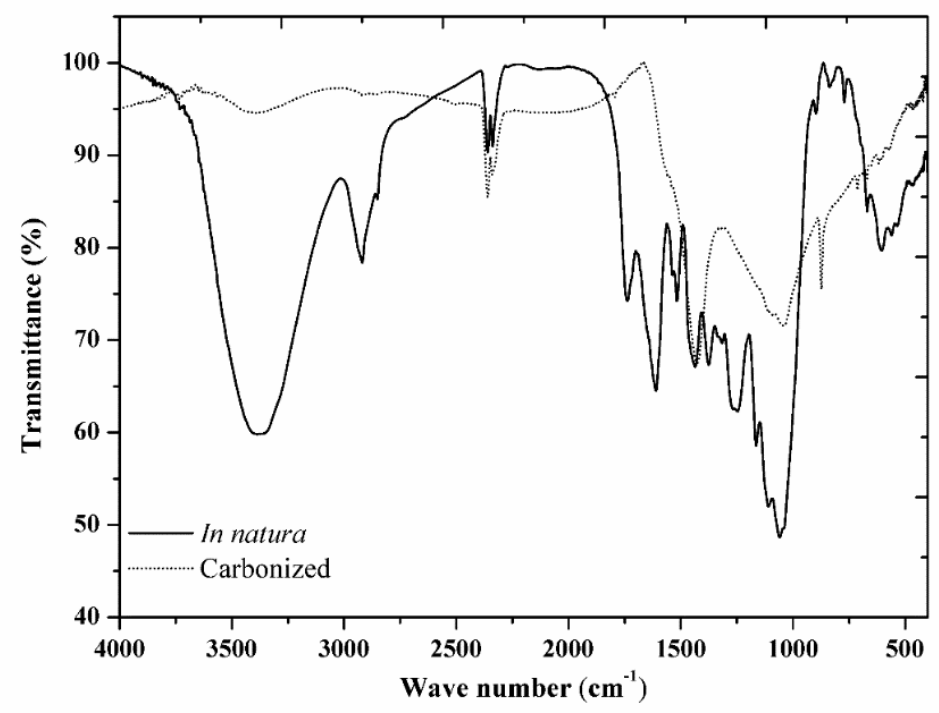

Source: Authors (2021).

\subsection{Effect of contact time and initial concentrations on AY 17 adsorption}

Figure 3 shows the effect of contact time ( $\mathrm{min}$ ) and initial concentrations in the adsorption process of acid yellow dye 17 for concentrations of $50,75,100$ and $150 \mathrm{mg} \mathrm{L}^{-1}$.

Figure 3 - Effect of initial concentrations and contact time on the adsorption process of AY 17 , at $20{ }^{\circ} \mathrm{C}, 200 \mathrm{rpm}$, pH 6.0 and $0.5 \mathrm{~g}$ of CA-CA700.

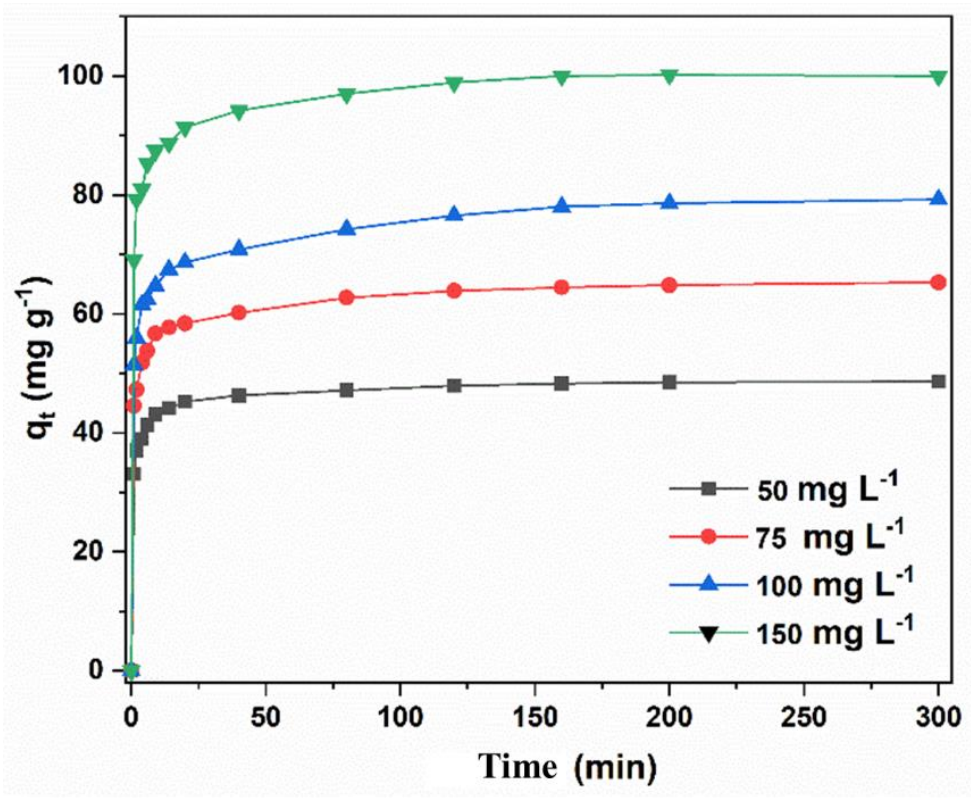

Source: Authors (2021).

At the beginning of the process, the adsorption rate increases rapidly up to $25 \mathrm{~min}$, followed by a gradual increase until reaching the equilibrium state, in $200 \mathrm{~min}$ (Figure 3). (Munagapati et al., 2021; Reza et al., 2020; Abdulhameed et al., 2019). 
The rapid adsorption of the dye at the beginning of the process is associated with the large availability of empty sites and the reduction in the rate with increasing interaction time indicates the increase in repulsive forces between the adsorbate molecules as the sites are occupied, as well as the saturation of the sites available for adsorption (Munagapati et al., 2021; Reza et al., 2020; Patil et al., 2015; Srivastava et al., 2006). The adsorption capacity of CA-CA700 for acid yellow dye 17 increased from $47.9 \pm$ $0.1 \mathrm{mg} \mathrm{g}^{-1}$ to $100.2 \pm 0.2 \mathrm{mg} \mathrm{g}^{-1}$ when the initial concentration of dye increased from 50 to $150 \mathrm{mg} \mathrm{L}^{-1}$, suggesting that this material is suitable for the treatment of textile effluents.

\subsection{Effect of pH on adsorption}

The effect of $\mathrm{pH}$ on the removal capacity of CA-CA700 is shown in Figure 4. The result shows that the AY 17 removal index decreases from $99 \%$ at $\mathrm{pH} 2.0$ to $92 \%$ at $\mathrm{pH} 9.0$, indicating a promising applicability of the material under real conditions for textile effluents.

Figure 4. Effect of $\mathrm{pH}$ on the adsorption of AY 17, at $20^{\circ} \mathrm{C}, 200 \mathrm{rpm}$, equilibrium time of $200 \mathrm{~min}, 0.5 \mathrm{~g}$ and $150 \mathrm{mg} \mathrm{L}{ }^{-1}$.

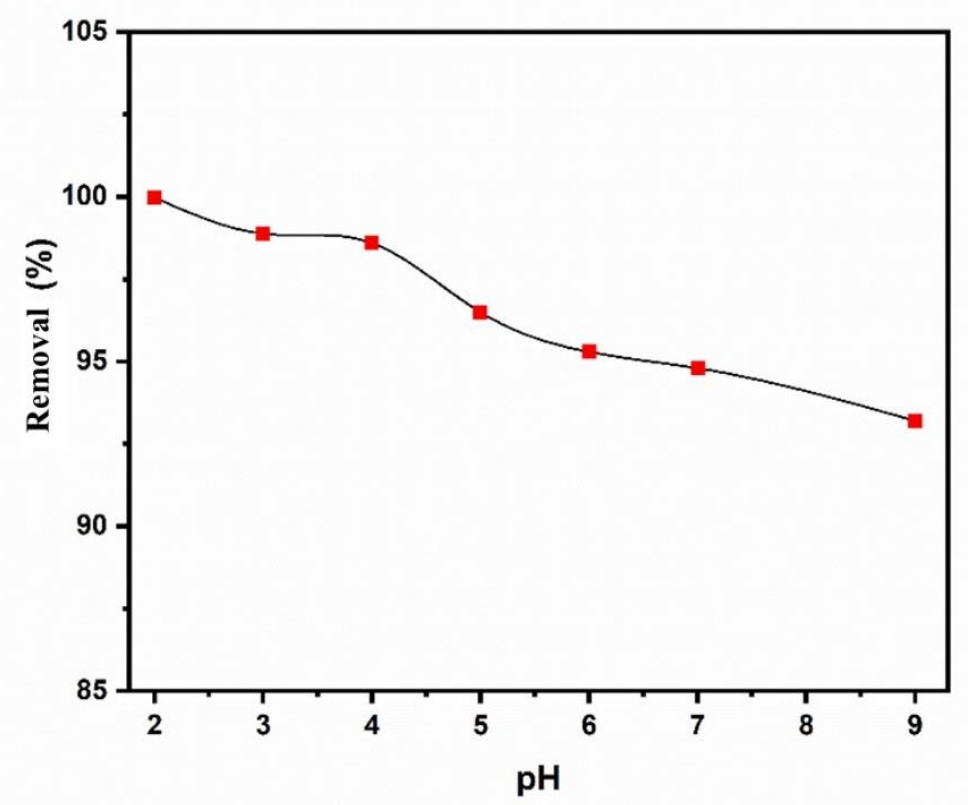

Source: Authors (2021).

According to the literature, adsorption is favored in an acidic medium for anionic dyes, because the surface protonation favors the interaction with the sulfonic groups of the dye through electrostatic forces (Bouhadjra et al., 2021; Felista et al., 2020; Jain et al., 2020; Cardoso et al., 2011). This phenomenon is due to the presence of sulfonate groups $\left(-\mathrm{SO}_{3} \mathrm{Na}\right)$ in the structure of the acid yellow dye 17 , which, in an aqueous medium, makes available the sulfonic groups $\left(-\mathrm{SO}_{3}{ }^{-}\right)$, allowing the occurrence of electrostatic interactions with the functional groups present on the surface of the CA-CA700. At pH below 7.0, the initially negative functional groups of CA-CA700 are partially neutralized by the addition of protons $\left(\mathrm{H}^{+}\right)$, enabling an electrostatically favorable interaction of the adsorbent with the anionic form of the dye in an aqueous medium, thus increasing the index of removal (Bouhadjra et al., 2021; Bhomick et al., 2018; Li et al., 2018). Higher removal rates of the acid yellow dye 17 at lower $\mathrm{pH}$ values is in accordance with the study by Patil et al., 2015, using rice husk as an adsorbent, in which a removal of $72.1 \%$ was obtained at $\mathrm{pH} 2$, value lower than that found in this study, being $99.8 \%$ at the same $\mathrm{pH}$.

In addition, Reza et al., 2020 and Munagapati et al., 2021 studied the adsorption of AY 17 on activated carbon, with a high removal capacity being reported in the $\mathrm{pH}$ range between 2.0 and 7.0. 


\subsection{Kinetic models}

The characterization of the adsorption kinetics provides important information about the adsorption mechanism, which is essential to evaluate the adsorption efficiency (Munagapati et al., 2021). Experimental data were fitted using pseudo-first-order and pseudo-second-order models. The linearized mathematical expression for the pseudo-first order model is shown in Equation 3 (Veit et al., 2014).

$$
\ln \left(q_{e}-q_{t}\right)=\ln q_{e}-k_{1} t
$$

where, $q_{t}\left(\mathrm{mg} \mathrm{g}^{-1}\right)$ and $q_{e}\left(\mathrm{mg} \mathrm{g}^{-1}\right)$ are the amount of solute adsorbed over time $\mathrm{t}$ and the amount adsorbed when equilibrium is reached, respectively, $\mathrm{k}_{1}\left(\mathrm{~min}^{-1}\right)$ is the pseudo-first order adsorption rate constant and $t(\mathrm{~min})$ is the contact time. Likewise, the linearized mathematical expression for pseudo-second order adsorption is shown in Equation 4.

$$
\frac{t}{q_{t}}=\frac{1}{q_{e}^{2} k_{2}}+\frac{1}{q_{e}} t
$$

where $\mathrm{k}_{2}\left(\mathrm{~g} \mathrm{mg}^{-1} \mathrm{~min}^{-1}\right)$ is the pseudo-second order adsorption rate constant.

Figure 5 shows the fits using Equations 3 and 4 of the experimental data for the pseudo-first order (Figure 5a) pseudosecond order (Figure $5 b$ ) models. The kinetic parameters obtained from the adjustments are shown in Table 2.

From Figure 5a and the parameters presented in Table 2, the pseudo first order kinetic model is not adequate to describe the adsorption process of dye AY 17 in CA-CA700. Considering the linear regression coefficients $\left(\mathrm{R}^{2}\right.$ adj) for all concentrations in this study, the pseudo-second order model better describes the adsorption process of AY 17 and suggests that the dye adsorption rate on the surface of CA-CA700 is strongly dependent on the number of species adsorbed on the surface of the adsorbent (availability of free sites), than the concentration of dye in the solution (Table 2). This behavior is evidenced in the low dependence on the velocity constant $\left(\mathrm{k}_{2}\right)$, Table 2 , as a function of concentration, in which almost no significant change is observed as a function of the concentration in the range from 75 to $150 \mathrm{mg} \mathrm{L}^{-1}$. 
Figure 5 - Adjustments to kinetic process of acid yellow dye 17 adsorption in CA-CA700, $0.5 \mathrm{~g}, 20{ }^{\circ} \mathrm{C}$ at $\mathrm{pH} 6.0$.
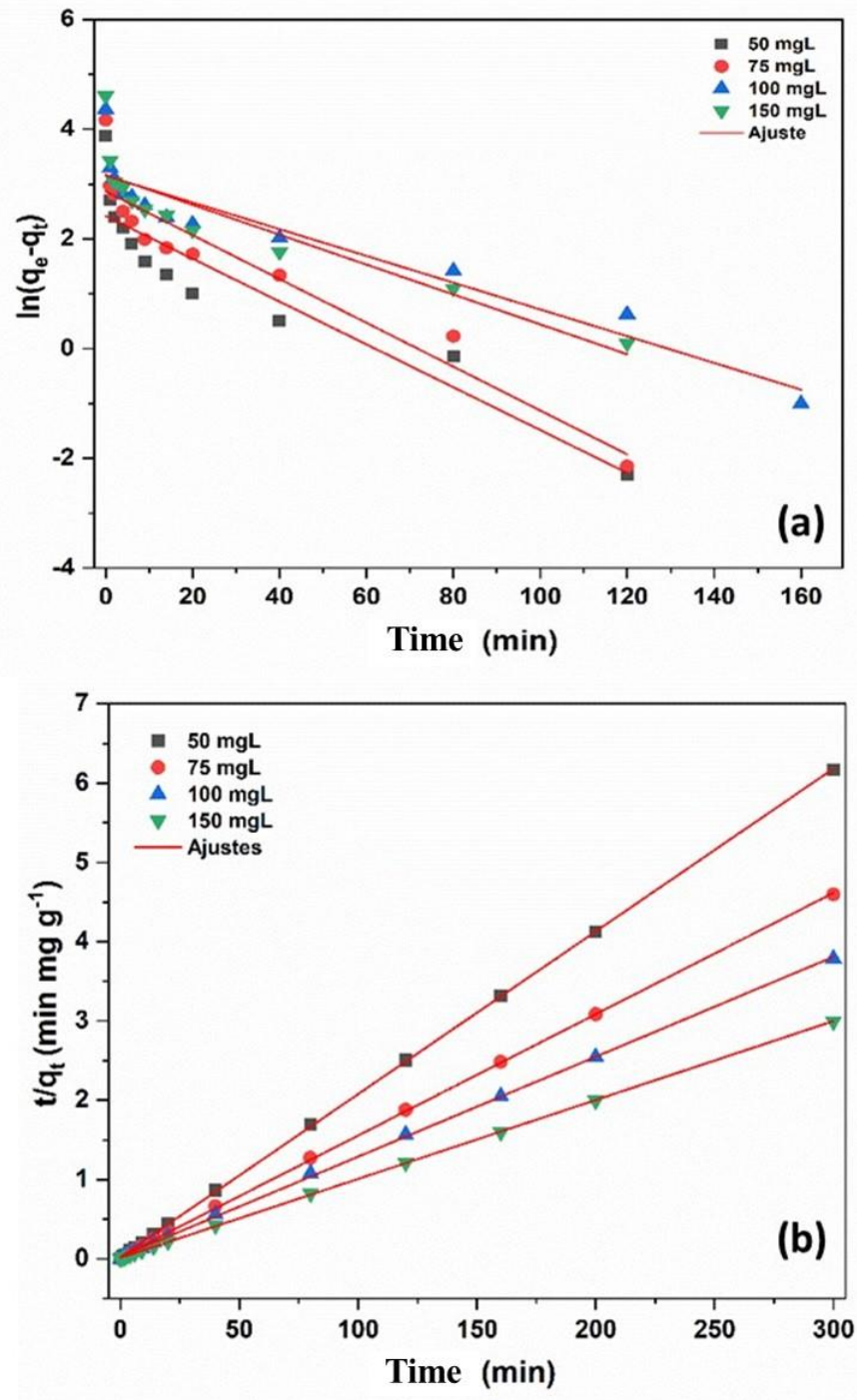

Source: Authors (2021).

Table 2 - Kinetic parameters for pseudo-first and pseudo-second orders models for acid yellow dye 17 (AY 17), 0.5 g of CACA700 at $20{ }^{\circ} \mathrm{C}, \mathrm{pH} 6.0$.

\begin{tabular}{|c|c|c|c|c|c|c|c|}
\hline \multirow{2}{*}{$\begin{array}{c}C o \\
\left(m g L^{-1}\right)\end{array}$} & \multirow[b]{2}{*}{$\begin{array}{c}q_{e, \exp } \\
\left(m g g^{-1}\right)\end{array}$} & \multicolumn{3}{|c|}{ pseudo-first order } & \multicolumn{3}{|c|}{ pseudo-second order } \\
\hline & & $\begin{array}{c}k_{I}\left(\mathrm{~min}^{-1}\right) \\
\times 10^{-3}\end{array}$ & $\begin{array}{c}q_{e l, c a l} \\
\left(m g g^{-1}\right)\end{array}$ & $R_{\text {adj }}^{2}$ & $\begin{array}{c}k_{2}\left(g \mathrm{mg}^{-1}\right) \\
x 10^{-3} \\
\end{array}$ & $\begin{array}{c}q_{e 2, c a l} \\
\left(m g g^{-1}\right)\end{array}$ & $R^{2}$ adj \\
\hline 50.0 & $47.9 \pm 0.1$ & $39 \pm 5$ & 11.2 & 0.8487 & $17 \pm 2$ & $48.7 \pm 0.2$ & 0.9999 \\
\hline 75.0 & $64.1 \pm 0.3$ & $40 \pm 4$ & 17.6 & 0.8849 & $9.5 \pm 0.5$ & $65.3 \pm 0.1$ & 0.9998 \\
\hline 100.0 & $78.7 \pm 0.2$ & $24 \pm 3$ & 23.3 & 0.8780 & $6 \pm 1$ & $79.3 \pm 0.1$ & 0.9996 \\
\hline 150.0 & $100.2 \pm 0.2$ & $27 \pm 4$ & 23.7 & 0.7709 & $8 \pm 1$ & $100.4 \pm 0.1$ & 0.9999 \\
\hline
\end{tabular}

Source: Authors (2021).

Another parameter used to identify the kinetic controlling mechanism of the adsorption process is the proximity between the values of qe calculated by the theoretical $\left(\mathrm{q}_{\mathrm{e}, \text { cal }}\right)$ and experimental $\left(\mathrm{q}_{\mathrm{e}, \text { exp }}\right)$ model, in this case, the closer the proximity between these parameters, the greater it is the applicability of the model (Munagapati et al., 2021; Habibi et al., 2018). Table 2 shows that the values of $\mathrm{q}_{\mathrm{e} 1 \text {, cal }}$ obtained by the pseudo-first model are much lower than the values of $\mathrm{q}_{\mathrm{e}}$, exp for all concentrations, 
confirming that this model does not describe the kinetic mechanism of adsorption of AY 17 in CA -CA700. On the other hand, it was observed that the values of $\mathrm{q}_{\mathrm{e} 2 \text {, cal }}$ for the pseudo-second order model are very close to the experimental values, confirming that the adsorption process follows pseudo-second order kinetics. Studies in the literature for different dyes indicate that the adsorption process on activated carbon is described by the pseudo-second order model (Karthik et al., 2019). Njoku et al., 2014, studied the activated carbon adsorption kinetics of AY 17 in a concentration range of 50 to $400 \mathrm{mg} \mathrm{L}^{-1}$ and reported that the pseudo-second order model best describes the kinetic process of AY 17. Likewise, recent studies carried out by Munagapati et al., 2021 show that the adsorption of AY17 obeys the pseudo-second order model, with $\mathrm{R}^{2}$ adj greater than 0.99 for six study temperatures. Other works involving adsorption of AY 17 on activated carbon also portray better adjustments to this model (Jedynak et al., 2019; Patil et al., 2015; Ahmad et al., 2014).

\subsection{Adsorption isotherms}

To evaluate the adsorption capacity of CA-CA700, adsorption isotherms obtained by the graphical relationship between $\mathrm{q}_{\mathrm{e}}$ and $\mathrm{C}_{\mathrm{e}}$ were used. The experimental data were adjusted according to the Langmuir, Freundlich and Temkin models, in order to obtain information regarding the specific surface properties and nature of the interactions between the adsorbate and the adsorbent (Munagapati et al., 2021; Njoku et al., 2014; Karthik et al., 2019). The Langmuir model (1918) suggests that the adsorption process occurs in monolayers and that the energy of the available sites is homogeneous (Njoku et al., 2014; Srivastava et al., 2006; Karthik et al., 2019). The mathematical expression for the linearized form of this model is shown in Equations 5 (Langmuir, 1918; Al-Ghouti \& Da'ana, 2020).

$$
\frac{C_{e}}{q_{e}}=\frac{1}{k_{b} q_{m}}+\frac{1}{q_{m}} C_{e}
$$

where $q_{m}\left(\mathrm{mg} \mathrm{g}^{-1}\right)$ and $q_{e}\left(\mathrm{mg} \mathrm{g}^{-1}\right)$ are the maximum adsorption capacity per monolayer and the amount of solute adsorbed at equilibrium respectively, $\mathrm{C}_{\mathrm{e}}\left(\mathrm{mg} \mathrm{L}^{-1}\right)$ is the concentration of adsorbate at equilibrium and $\mathrm{k}_{b}\left(\mathrm{~L} \mathrm{mg}^{-1}\right)$ is the Langmuir constant associated with the free energy of the adsorption process.

Unlike the Langmuir model, the isotherm model proposed by Freundlich (1906) (Munagapati et al., 2021; Karthik et al., 2019); proposes that the adsorption occurs in multilayers, and that the adsorption energy decreases logarithmically as the surface of the adsorbent is covered (Munagapati et al., 2021; Kannaujiya et al., 2021; Njoku et al., 2014; Karthik et al., 2019; Al-Ghouti and Da'ana, 2020). Equation 6 shows the linearized form of the Freundlich model.

$$
\ln q_{e}=\ln k_{f}+\frac{1}{n} \ln C_{e}
$$

Where $k_{f}\left(\mathrm{mg} \mathrm{g}^{-1}\right)\left(\mathrm{L} \mathrm{mg}^{-1}\right)^{1 / \mathrm{n}}$ and $\mathrm{n}$ are the Freundlich constant, related to adsorption capacity, and adsorption intensity, respectively (Al-Ghouti \& Da'ana, 2020; Piccin et al., 2011; Inyinbor et al., 2016).

The Temkin isotherm model, on the other hand, assumes that the heat of adsorption of all molecules in the layer decreases linearly with surface coverage and that the adsorbent sites are heterogeneous (Njoku et al., 2014; Inyinbor et al., 2016; Mane et al., 2007; Kataria et al., 2016). The mathematical expression of this model is shown in equation 07 (Saadi et al., 2015).

$$
\boldsymbol{q}_{e}=\boldsymbol{B} \ln \left(\boldsymbol{A} \boldsymbol{C}_{e}\right)
$$

In linearized form, the equation that describes the Temkin isotherm is commonly expressed as:

$$
q_{e}=B \ln A+B \ln C_{e}
$$


where $\mathrm{B}=\mathrm{RT} / \mathrm{b}$ and $\mathrm{b}\left(\mathrm{J} \mathrm{mol}^{-1}\right)$ is the Temkin constant related to the heat of adsorption, $\mathrm{A}\left(\mathrm{L} \mathrm{g}^{-1}\right)$ is the Temkin isotherm constant, $\mathrm{R}\left(8.314 \mathrm{~J} \mathrm{~mol}^{-1} \mathrm{~K}^{-1}\right)$ is the universal gas constant and $\mathrm{T}(\mathrm{K})$ is the absolute temperature (Njoku et al., 2014; Piccin et al., 2011; Inyinbor et al., 2016; Kataria et al., 2016).

The adjustments using the Langmuir, Freundlich and Temkin (Saadi et al., 2015) models for the adsorption of AY 17 at $20^{\circ} \mathrm{C}$, obtained from Equations 5, 6 and 8, are shown in Figure 6. The parameters obtained from the adjustments are shown in Table 3. The results show that the adsorption equilibrium data of AY17 is better described by the Freundlich model, whose $\mathrm{R}^{2}$ adj of the adjustments was 0.9873 and the adsorption capacity constant $\mathrm{k}_{f}$ equal to $47.9\left(\mathrm{mg} \mathrm{g}^{-1}\right)\left(\mathrm{L} \mathrm{mg}^{-1}\right)^{1 / \mathrm{n}}$ (Table 3). The value of the Freundlich constant (n) equal to 5.95 suggests that the adsorption process between AY 17 and CA-CA700 is favorable, because the higher the value of $\mathrm{n}$ (smaller the $1 / \mathrm{n}$ ratio), the stronger it is the interaction between the adsorbate and the adsorbent (Obaid et al., 2016; Lang et al., 2013; Al-Ghouti and Da'ana, 2020; Piccin et al., 2011; Inyinbor et al., 2016; Saadi et al., 2015; Delle Site, 2001). In addition, this model assumes that the process of adsorption of AY17 occurs mostly in multilayers (Njoku et al., 2014; Patil et al., 2015; Ahmad et al., 2014; Ashraf et al., 2013), a non-homogeneous surface, where the energy distribution in the sites is heterogeneous and strictly exponential (Al-Ghouti and Da'ana, 2020; Piccin et al., 2011; Inyinbor et al., 2016; Delle Site, 2001; Febrianto et al., 2009; Ahmad et al., 2014). Patil et al., 2015 when studying the models of Langmuir and Freundlich in the adsorption of dye AY 17, they also identified that the Freundlich model, in its linearized form, better adjusted to the experimental data, obtaining $n$ equal to 1.85 and $\mathrm{R}^{2}$ adj equal to 0.996 confirming that the adsorption of $\mathrm{AY}$ 17 occurs preferentially in multilayers. Ashraf et al., 2013 studied the adsorption of AY 17 on activated carbon produced from T. Angustata L. finding excellent fits to the Freundlich model.

Figure 6 - Linear adjustment by Langmuir, Freundlich and Temkin models of the adsorption isotherm of AY 17 at $20^{\circ} \mathrm{C}, \mathrm{Ph} 6.0$ and $0.5 \mathrm{~g}$ of CA-CA700.
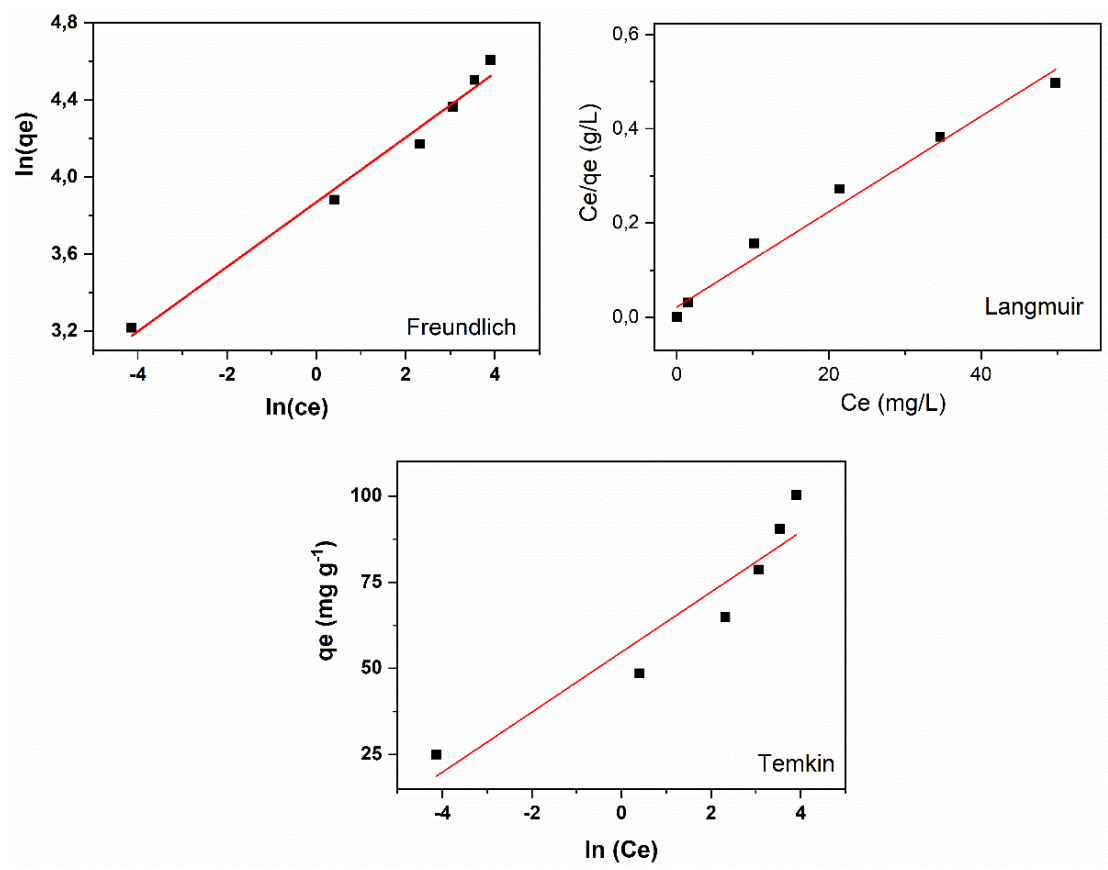

Source: Authors (2021). 
Table 3 - Adjustment parameters for the acid yellow dye adsorption isotherm models 17 at $20{ }^{\circ} \mathrm{C}, \mathrm{pH} 6.0$ and $0.5 \mathrm{~g}$ of $\mathrm{CA}$ CA700.

\begin{tabular}{|c|c|c|c|c|c|c|c|c|}
\hline \multicolumn{3}{|c|}{ Langmuir } & \multicolumn{3}{|c|}{ Freundlich } & \multicolumn{3}{|c|}{ Temkin } \\
\hline $\begin{array}{c}K_{b} \\
\left(L m g^{-1}\right)\end{array}$ & $\begin{array}{c}q_{m} \\
\left(m g g^{-1}\right)\end{array}$ & $R_{a d j}^{2}$ & $k_{f} *$ & $n$ & $R_{a d j}^{2}$ & $\begin{array}{c}A \\
\left(L g^{-1}\right)\end{array}$ & $\begin{array}{c}B \\
\left(J \mathrm{~mol}^{-1}\right)\end{array}$ & $R_{a d j}^{2}$ \\
\hline 0.467 & 98.8 & 0.9236 & 47.9 & 5.95 & 0.9873 & 537.5 & 280 & 0.8717 \\
\hline
\end{tabular}

* $\left(\mathrm{mg} \mathrm{g}^{-1}\right)\left(\mathrm{L} \mathrm{mg}^{-1}\right)^{1 / \mathrm{n}}$. Source: Authors (2021).

\section{Conclusion}

The data reported in this study indicated that the charcoal produced from the açaí bunch in an open atmosphere, without the use of inert gases that make the synthesis route more expensive, is promising for the treatment of effluents and, therefore, is an important alternative for the reduction of these waste in the environment. CA-CA700 is effective for the removal of acid yellow 17, showing high adsorptive capacity under the conditions studied. The equilibrium time is reached with 200 min and the adsorption process of AY 17 in the CA-CA700 is described by the pseudo-second order kinetic model while the Freundlich isotherm model indicates that the interaction between adsorbent and adsorbate is favorable and occurs in multilayers.

Our results represent a nice contribution and an important and necessary step in the low-cost materials adsorbents for removal dyes in the aqueous solutions. In future publications, the authors propose the use of adsorbent materials obtained from the plant biomass of the Amazon biome, mainly from extractivism, and composite materials for the treatment of textile effluents, heavy metals, drugs and other contaminants in water bodies and soil.

\section{Acknowledgments}

The authors are grateful to the Ceramic Materials Synthesis Laboratory (LABSMAC, Campina Grande, Brazil) for making available the BET and FTIR facilities used in this work. Thanks are due to the Brazilian agencies CNPq (Process number

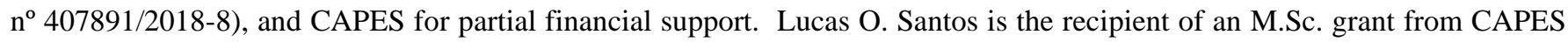
(Finance Code 001).

\section{References}

Abdulhameed, A. S., Mohammad, A. K. T., \& Jawad, A. H. (2019). Application of response surface methodology for enhanced synthesis of chitosan tripolyphosphate/TiO2 nanocomposite and adsorption of reactive orange 16 dye. J. Clean. Prod., 232, 43-56. https://doi.org/10.1016/j.jclepro.2019.05.291.

Achour, Y., Bahsis, L., Ablouh, E. H., Yazid, H., Laamari, M. R., \& Haddad, M. El (2021). Insight into adsorption mechanism of Congo red dye onto Bombax Buonopozense bark Activated-carbon using Central composite design and DFT studies. Surfaces and Interfaces, 23 , 100977. https://doi.org/10.1016/j.surfin.2021.100977.

Ahmad, M. A., Ahmad Puad, N. A., \& Bello, O. S. (2014). Kinetic, equilibrium and thermodynamic studies of synthetic dye removal using pomegranate peel activated carbon prepared by microwave-induced KOH activation. Water Resour. Ind., 6, 18-35. https://doi.org/10.1016/j.wri.2014.06.002.

Al-Ghouti, M. A., \& Da'ana, D. A. (2020). Guidelines for the use and interpretation of adsorption isotherm models: A review. J. Hazard. Mater., 393 , 122383. https://doi.org/10.1016/j.jhazmat.2020.122383.

Alam, M. M., Hossain, M. A., Hossain, M. D., Johir, M. A. H., Hossen, J., Rahman, M. S., Zhou, J. L., Hasan, A. T. M. K., Karmakar, A. K., \& Ahmed, M. B. (2020). The potentiality of rice husk-derived activated carbon: From synthesis to application. Processes, 8. https://doi.org/10.3390/pr8020203.

Alkathiri, D. S. S., Sabri, M. A., Ibrahim, T. H., ElSayed, Y. A., \& Jumean, F. (2020). Development of activated carbon fibers for removal of organic contaminants. Int. J. Environ. Sci. Technol., 17, 4841-4852. https://doi.org/10.1007/s13762-020-02808-8.

Ani, J. U., Akpomie, K. G., Okoro, U. C., Aneke, L. E., Onukwuli, O. D., \& Ujam, O. T. (2020). Potentials of activated carbon produced from biomass materials for sequestration of dyes, heavy metals, and crude oil components from aqueous environment. Appl. Water Sci., 10, 1-11. https://doi.org/10.1007/s13201-0201149-8. 
Ashraf, M. A., Hussain, M., Mahmood, K., Wajid, A., Yusof, M., Alias, Y., \& Yusoff, I. (2013). Removal of acid yellow-17 dye from aqueous solution using eco-friendly biosorbent. Desalin. Water Treat., 51, 4530-4545. https://doi.org/10.1080/19443994.2012.747187.

Benkhaya, S., M' rabet, S., \& El Harfi, A. (2020). A review on classifications, recent synthesis and applications of textile dyes. Inorg. Chem. Commun., 115, 107891. https://doi.org/10.1016/j.inoche.2020.107891.

Berradi, M., Hsissou, R., Khudhair, M., Assouag, M., Cherkaoui, O., El Bachiri, A., \& El Harfi, A. (2019). Textile finishing dyes and their impact on aquatic environs. Heliyon, 5. https://doi.org/10.1016/j.heliyon.2019.e02711.

Bhomick, P. C., Supong, A., Baruah, M., Pongener, C., \& Sinha, D. (2018). Pine Cone biomass as an efficient precursor for the synthesis of activated biocarbon for adsorption of anionic dye from aqueous solution: Isotherm, kinetic, thermodynamic and regeneration studies. Sustain. Chem. Pharm., 10, 41-49. https://doi.org/10.1016/j.scp.2018.09.001.

Bouhadjra, K., Lemlikchi, W., Ferhati, A., \& Mignard, S. (2021). Enhancing removal efficiency of anionic dye (Cibacron blue) using waste potato peels powder. Sci. Rep., 11, 1-10. https://doi.org/10.1038/s41598-020-79069-5.

Bulca, Ö., Palas, B., Atalay, S., \& Ersöz, G. (2021). Performance investigation of the hybrid methods of adsorption or catalytic wet air oxidation subsequent to electrocoagulation in treatment of real textile wastewater and kinetic modelling. J. Water Process Eng., 40. https://doi.org/10.1016/j.jwpe.2020.101821.

Castro, A. S., Franco, C. R., \& Cidade, M. J. A. (2018). Adsorption of dyes indosol blue, Indosol orange and drimarene red in aqueous solution by white clay. Rev. Virtual Quim., 10, 1502-1515. https://doi.org/10.21577/1984-6835.20180102.

Chen, F., Zhu, J., Yang, Y., \& Wang, L. (2020). Assessing environmental impact of textile production with water alkalization footprint. Sci. Total Environ., 719, 137522. https://doi.org/10.1016/j.scitotenv.2020.137522.

Delle Site, A. (2001). Factors affecting sorption of organic compounds in natural sorbent/water systems and sorption coefficients for selected pollutants. A review. J. Phys. Chem. Ref. Data, 30, 187-439. https://doi.org/10.1063/1.1347984.

Febrianto, J., Kosasih, A. N., Sunarso, J., Ju, Y. H., Indraswati, N., \& Ismadji, S. (2009). Equilibrium and kinetic studies in adsorption of heavy metals using biosorbent: A summary of recent studies. J. Hazard. Mater., 162, 616-645. https://doi.org/10.1016/j.jhazmat.2008.06.042.

Felista, M. M., Wanyonyi, W. C., \& Ongera, G. (2020). Adsorption of anionic dye (Reactive black 5) using macadamia seed Husks: Kinetics and equilibrium studies. Sci. African, 7, e00283. https://doi.org/10.1016/j.sciaf.2020.e00283.

Foo, K. Y., \& Hameed, B. H. (2012). Preparation of activated carbon by microwave heating of langsat (Lansium domesticum) empty fruit bunch waste. Bioresour. Technol., 116, 522-525. https://doi.org/10.1016/j.biortech.2012.03.123.

Guaratini, C. C. I., \& Zanoni, M. V. B. (2000). Corantes têxteis. Quim. Nova, 23, 71-78.

Habibi, A., Belaroui, L.S., Bengueddach, A., López Galindo, A., Sainz Díaz, C. I., \& Peña, A. (2018). Adsorption of metronidazole and spiramycin by an Algerian palygorskite. Effect of modification with tin. Microporous Mesoporous Mater., 268, 293-302. https://doi.org/10.1016/j.micromeso.2018.04.020.

Hamza, W., Dammak, N., Hadjltaief, H. B., Eloussaief, M., \& Benzina, M. (2018). Sono-assisted adsorption of Cristal Violet dye onto Tunisian Smectite Clay: Characterization, kinetics and adsorption isotherms. Ecotoxicol. Environ. Saf., 163, 365-371. https://doi.org/10.1016/j.ecoenv.2018.07.021.

Haseeb, M., Kot, S., Hussain, H. I., Mihardjo, L. W. W., \& Saluga, P. (2020). Modelling the non-linear energy intensity effect based on a quantile-on-quantile approach: The case of textiles manufacturing in asian countries. Energies, 13. https://doi.org/10.3390/en13092229.

Hassaan, M. A., Nemr, A. El, \& Madkour, F. F. (2016). Application of Ozonation and UV assisted Ozonation for Decolorization of Direct Yellow 50 in Sea water. Pharm. Chem. J., 3, 131-138.

Heidarinejad, Z., Dehghani, M. H., Heidari, M., Javedan, G., Ali, I., \& Sillanpää, M. (2020). Methods for preparation and activation of activated carbon: a review. Environ. Chem. Lett., 18, 393-415. https://doi.org/10.1007/s10311-019-00955-0.

Hynes, N. R. J., Kumar, J. S., Kamyab, H., Sujana, J. A. J., Al-Khashman, O. A., Kuslu, Y., Ene, A., \& Suresh Kumar, B. (2020). Modern enabling techniques and adsorbents based dye removal with sustainability concerns in textile industrial sector -A comprehensive review. J. Clean. Prod., 272, 122636. https://doi.org/10.1016/j.jclepro.2020.122636.

Ignachewski, F., Fujiwara, T., Química, D. De, Centro-oeste, U.E., Camargo, R., Sá, V. De, Pr, G., Física, D. De, Centro-oeste, U.E., Camargo, R., Sá, V. De, Pr, G., Carneiro, L.M., \& Tauchert, E. (2010). Degradação de corantes reativos por processo foto-fenton envolvendo o uso de peneira molecular 4a modificada com fe ${ }^{3+}$. Quim. Nova, 33, 1640-1645.

Inyinbor, A. A., Adekola, F. A., \& Olatunji, G. A. (2016). Kinetics, isotherms and thermodynamic modeling of liquid phase adsorption of Rhodamine B dye onto Raphia hookerie fruit epicarp. Water Resour. Ind., 15, 14-27. https://doi.org/10.1016/j.wri.2016.06.001.

Langmuir, I. (1918). Adsorption of Gases on Glass, Mica and Platinum. the Adsorption of Gases on Plane Surfaces of Glass, Mica and Platinum. J. Am. Chem. Soc., 40, 1361-1403.

Jain, S. N., Tamboli, S. R., Sutar, D. S., Jadhav, S. R., Marathe, J. V., Shaikh, A. A., \& Prajapati, A. A. (2020). Batch and continuous studies for adsorption of anionic dye onto waste tea residue: Kinetic, equilibrium, breakthrough and reusability studies. J. Clean. Prod., $252, \quad 119778$. https://doi.org/10.1016/j.jclepro.2019.119778.

Jedynak, K., Wideł, D., \& Rędzia, N. (2019). Removal of rhodamine b (A basic dye) and acid yellow 17 (an acidic dye) from aqueous solutions by ordered mesoporous carbon and commercial activated carbon. Colloids and Interfaces, 3. https://doi.org/10.3390/colloids3010030. 
Kannaujiya, M. C., Prajapati, A. K., Mandal, T., Das, A. K., \& Mondal, M. K. (2021). Extensive analyses of mass transfer, kinetics, and toxicity for hazardous acid yellow 17 dye removal using activated carbon prepared from waste biomass of Solanum melongena. Biomass Convers. Biorefinery., https://doi.org/10.1007/s13399-020-01160-8.

Karthik, V., Saravanan, K., Patra, C., Ushadevi, B., Vairam, S., \& Selvaraju, N. (2019). Biosorption of Acid Yellow 12 from simulated wastewater by nonviable T. harzianum: kinetics, isotherm and thermodynamic studies. Int. J. Environ. Sci. Technol., 16, 6895-6906. https://doi.org/10.1007/s13762-018-2073-4.

Kataria, N., Garg, V. K., Jain, M., \& Kadirvelu, K. (2016). Preparation, characterization and potential use of flower shaped Zinc oxide nanoparticles (ZON) for the adsorption of Victoria Blue B dye from aqueous solution. Adv. Powder Technol., 27, 1180-1188. https://doi.org/10.1016/j.apt.2016.04.001.

Khatri, J., Nidheesh, P. V., Anantha Singh, T. S., \& Suresh Kumar, M. (2018). Advanced oxidation processes based on zero-valent aluminium for treating textile wastewater. Chem. Eng. J., 348, 67-73. https://doi.org/10.1016/j.cej.2018.04.074.

Khattab, T. A., Abdelrahman, M. S., \& Rehan, M. (2020). Textile dyeing industry: environmental impacts and remediation. Environ. Sci. Pollut. Res., 27, 38033818. https://doi.org/10.1007/s11356-019-07137-z.

Kishor, R., Purchase, D., Saratale, G. D., Saratale, R. G., Ferreira, L. F. R., Bilal, M., Chandra, R., \& Bharagava, R. N. (2021). Ecotoxicological and health concerns of persistent coloring pollutants of textile industry wastewater and treatment approaches for environmental safety. J. Environ. Chem. Eng., 9 , 105012. https://doi.org/10.1016/j.jece.2020.105012.

Lang, W., Sirisansaneeyakul, S., Ngiwsara, L., Mendes, S., Martins, L.O., Okuyama, M., \& Kimura, A. (2013). Characterization of a new oxygen-insensitive azoreductase from Brevibacillus laterosporus TISTR1911: Toward dye decolorization using a packed-bed metal affinity reactor. Bioresour. Technol., 150, 298306. https://doi.org/10.1016/j.biortech.2013.09.124.

Li, J., Wang, S., Peng, J., Lin, G., Hu, T., \& Zhang, L. (2018). Selective Adsorption of Anionic Dye from Solutions by Modified Activated Carbon. Arab. J. Sci. Eng., 43, 5809-5817. https://doi.org/10.1007/s13369-017-3006-0.

Machrouhi, A., Farnane, M., Elhalil, A., Elmoubarki, R., Abdennouri, M., Barka, N., Qourzal, S., \& Tounsadi, H. (2018). Effectiveness of beetroot seeds and H3PO4 activated beetroot seeds for the removal of dyes from aqueous solutions. J. Water Reuse Desalin., 8, 522-531. https://doi.org/10.2166/wrd.2017.034.

Mahmoud, M. E., Abdelfattah, A. M., Tharwat, R. M., \& Nabil, G. M. (2020). Adsorption of negatively charged food tartrazine and sunset yellow dyes onto positively charged triethylenetetramine biochar: Optimization, kinetics and thermodynamic study. J. Mol. Liq., 318 , 114297. https://doi.org/10.1016/j.molliq.2020.114297.

Mane, V. S., Mall, I. D., \& Srivastava, V. C. (2007). Use of bagasse fly ash as an adsorbent for the removal of brilliant green dye from aqueous solution. Dye. Pigment., 73, 269-278. https://doi.org/10.1016/j.dyepig.2005.12.006.

Munagapati, V. S., Wen, H. Y., Vijaya, Y., Wen, J. C., Wen, J. H., Tian, Z., Reddy, G. M., \& Raul Garcia, J. (2021). Removal of anionic (Acid Yellow 17 and Amaranth) dyes using aminated avocado (Persea americana) seed powder: adsorption/desorption, kinetics, isotherms, thermodynamics, and recycling studies. Int. J. Phytoremediation, 23, 911-923. https://doi.org/10.1080/15226514.2020.1866491.

Nambela, L., Haule, L.V., \& Mgani, Q. (2020). A review on source, chemistry, green synthesis and application of textile colorants. J. Clean. Prod., $246,119036$. https://doi.org/10.1016/j.jclepro.2019.119036.

Njoku, V. O., Foo, K. Y., Asif, M., \& Hameed, B. H. (2014). Preparation of activated carbons from rambutan (Nephelium lappaceum) peel by microwaveinduced KOH activation for acid yellow 17 dye adsorption. Chem. Eng. J., 250, 198-204. https://doi.org/10.1016/j.cej.2014.03.115.

Obaid, M. K., Abdullah, L. C., \& Idan, I. J. (2016). Removal of Reactive Orange 16 Dye from Aqueous Solution by Using Modified Kenaf Core Fiber. J. Chem., 2016, 1-8. https://doi.org/10.1155/2016/4262578.

Panwar, N. L., \& Pawar, A. (2020). Influence of activation conditions on the physicochemical properties of activated biochar: a review. Biomass Convers. Biorefinery., https://doi.org/10.1007/s13399-020-00870-3.

Paredes-Quevedo, L. C., González-Caicedo, C., Torres-Luna, J. A., \& Carriazo, J. G. (2021). Removal of a Textile Azo-Dye (Basic Red 46) in Water by Efficient Adsorption on a Natural Clay. Water. Air. Soil Pollut., 232. https://doi.org/10.1007/s11270-020-04968-2.

Parveen, K., \& Rafique, U. (2018). Development of cobalt-doped alumina hybrids for adsorption of textile effluents. Adsorpt. Sci. Technol., 36, 182-197. https://doi.org/10.1177/0263617416687563.

Patil, C., Ratnamala, G. M., Channamallayya, S. T., \& Belagavi, K. (2015). Adsorption Studies for Removal of Acid yellow 17 using Activated Rice Husk. Inter. Res. J. of Eng. and Techn., 769-774.

Piccin, J. S., Dotto, G. L., \& Pinto, L. A. A. (2011). Adsorption isotherms and thermochemical data of FDandC RED N ${ }^{\circ} 40$ Binding by chitosan. Brazilian J. Chem. Eng., 28, 295-304. https://doi.org/10.1590/S0104-66322011000200014.

Ghaly A. E, Ananthashankar R, Alhattab M, \& Ramakrishnan V. V (2014). Production, Characterization and Treatment of Textile Effluents: A Critical Review. J. Chem. Eng. Process Technol., 05. https://doi.org/10.4172/2157-7048.1000182.

Raman, C. D., \& Kanmani, S. (2016). Textile dye degradation using nano zero valent iron: A review. J. Environ. Manage., 177, 341-355. https://doi.org/10.1016/j.jenvman.2016.04.034.

Reza, M. S., Yun, C. S., Afroze, S., Radenahmad, N., Bakar, M. S. A., Saidur, R., Taweekun, J., \& Azad, A. K. (2020). Preparation of activated carbon from biomass and its' applications in water and gas purification, a review. Arab J. Basic Appl. Sci., 27, 208-238. https://doi.org/10.1080/25765299.2020.1766799.

Roy, U., Sengupta, S., Das, P., Bhowal, A., \& Datta, S. (2018). Integral approach of sorption coupled with biodegradation for treatment of azo dye using Pseudomonas sp.: batch, toxicity, and artificial neural network. 3 Biotech, 8, 1-11. https://doi.org/10.1007/s13205-018-1215-1. 
Saadi, R., Saadi, Z., Fazaeli, R., \& Fard, N. E. (2015). Monolayer and multilayer adsorption isotherm models for sorption from aqueous media. Korean J. Chem. Eng., 32, 787-799. https://doi.org/10.1007/s11814-015-0053-7.

Salleh, M. A. M., Mahmoud, D. K., Karim, W. A. W. A., \& Idris, A. (2011). Cationic and anionic dye adsorption by agricultural solid wastes: A comprehensive review. Desalination, 280, 1-13. https://doi.org/10.1016/j.desal.2011.07.019.

Sarkar, S., Banerjee, A., Halder, U., Biswas, R., \& Bandopadhyay, R. (2017). Degradation of Synthetic Azo Dyes of Textile Industry: a Sustainable Approach Using Microbial Enzymes. Water Conserv. Sci. Eng., 2, 121-131. https://doi.org/10.1007/s41101-017-0031-5.

Shindhal, T., Rakholiya, P., Varjani, S., Pandey, A., Ngo, H. H., Guo, W., Ng, H. Y., \& Taherzadeh, M. J. (2021). A critical review on advances in the practices and perspectives for the treatment of dye industry wastewater. Bioengineered, 12, 70-87. https://doi.org/10.1080/21655979.2020.1863034.

Shoaib, A. G. M., El-Sikaily, A., El Nemr, A., \& Mohamed, A. E. D. A., Hassan, A. A. (2020). Preparation and characterization of highly surface area activated carbons followed type IV from marine red alga (Pterocladia capillacea) by zinc chloride activation. Biomass Convers. Biorefinery., https://doi.org/10.1007/s13399-020-00760-8.

Sing, K. S. W. (1982). Reporting physisorption data for gas / solid systems with Special Reference to the Determination of S. Pure Appl. Chem., 54, $2201-2218$.

Srivastava, V. C., Swamy, M. M., Mall, I. D., Prasad, B., \& Mishra, I. M. (2006). Adsorptive removal of phenol by bagasse fly ash and activated carbon: Equilibrium, kinetics and thermodynamics. Colloids Surfaces A Physicochem. Eng. Asp., 272, 89-104. https://doi.org/10.1016/j.colsurfa.2005.07.016.

Ugwu, E. I., \& Agunwamba, J. C. (2020). A review on the applicability of activated carbon derived from plant biomass in adsorption of chromium, copper, and zinc from industrial wastewater. Environ. Monit. Assess., 192. https://doi.org/10.1007/s10661-020-8162-0.

Vacchi, F. I., Albuquerque, A. F., Vendemiatti, J. A., Morales, D. A., Ormond, A. B., Freeman, H. S., Zocolo, G. J., Zanoni, M. V. B., \& Umbuzeiro, G. (2013). Chlorine disinfection of dye wastewater: Implications for a commercial azo dye mixture. Sci. Total Environ., 442, 302-309. https://doi.org/10.1016/j.scitotenv.2012.10.019.

Veit, M. T., Bedin, S., Gonçalves, G. C., Palácio, S. M., \& Fagundes-Klen, M. R. (2014). Utilização do resíduo de erva-mate como material adsorvente do corante azul de metileno. Eclet. Quim., 39, 227-243.

Verma, K., Saha, G., Kundu, L. M., \& Dubey, V. K. (2019). Biochemical characterization of a stable azoreductase enzyme from Chromobacterium violaceum: Application in industrial effluent dye degradation. Int. J. Biol. Macromol., 121, 1011-1018. https://doi.org/10.1016/j.ijbiomac.2018.10.133.

Yusop, M. F. M., Ahmad, M. A., Rosli, N. A., Gonawan, F. N., \& Abdullah, S. J. (2021). Scavenging malachite green dye from aqueous solution using durian peel based activated carbon. Malaysian J. Fundam. Appl. Sci., 17, 95-103. https://doi.org/10.11113/MJFAS.V17N1.2173.

Zoroufchi Benis, K., Motalebi Damuchali, A., McPhedran, K. N., \& Soltan, J. (2020). Treatment of aqueous arsenic - A review of biosorbent preparation methods. J. Environ. Manage., 273, 111126. https://doi.org/10.1016/j.jenvman.2020.111126. 